\title{
Blackchested Prinia Prinia flavicans in Breeding Plumage at Satara, Kruger National Park
}

\author{
H. ROOME \\ P.O. Box 11078, Brooklyn, 0011 Republic of South Africa.
}

Koedoe 31: 245 (1988). ISSN 0075-6458.

On 8 October 1986 a pair of Blackchested Prinia Prinia flavicans in breeding plumage was observed in the camping area of Satara Rest Camp, Kruger National Park. Playing and replaying a tape recording of the call of a Pearlspotted Owl Glaucidium perlatum, in order to see what avian activity would be aroused, the recording attracted Blackeyed Bulbul Pycnonotus barbatus, Whitebellied Sunbird Nectarinia talatala and Tawnyflanked Prinia Prinia subflava, in addition to the pair of Blackchested Prinia, all highly excited and in search of the intruding Pearlspotted Owl. The birds homed in on the source of the call and all species were observed from a distance of some $2 \mathrm{~m}-3 \mathrm{~m}$.

Although recorded previously from the Kruger National Park (Newman 1980, Birds of Southern Africa 1: Kruger National Park, Johannesburg: Macmillan) in non-breeding plumage and also referred to by Milstein \& Milstein (1981, Koedoe 24: 109-117) as a species which they probably observed near Punda Milia (in winter plumage), the Blackchested Prinia recorded at Satara were most obliging and it was possible to positively identify the presence of this species in the Kruger National Park in its breeding plumage. 